\section{Dividend Payouts, Firm Characteristics Under Agency Factors' Mediation in Pakistan}

\author{
Tayyaba Ashraf ${ }^{1}$, Javed Iqbal ${ }^{2}$, Shehzad Akhtar ${ }^{3}$
}

The Journal of Educational Paradigms 2019, Vol. 01(02) 57-63

(C) Authors

ISSN (Print): 2709-202X

ISSN (Online): 2709-2038

DOI: $10.47609 / 0102022019$

\begin{abstract}
Under the bilateral approach of the impact of dividend pay-outs with the mediating role of Agency variables, this paper tries to examine its effects on enterprise value, earning per share, stock performance (including Stock Return \& Volatility). The mediation test performed by inspecting direct and indirect relationships of dividend pay-out, firm characteristics, and agency factors on a sample size of 130 Pakistani listed firms over eleven years. Results of a study expose the agency factors (such as free cashflows and total institutional ownership structure) role; free cash flow does not mediate the relationship of dividend pay-outs with earning per share and stock volatility separately. Total institutional ownership structure mediates dividend pay-out relation with enterprise value and stock return $\&$ volatility. These mixed results contribute to the current literature of finance, specifically in the Pakistani context being an emerging economy.
\end{abstract}

Keywords: Dividend Pay-Outs, Firm Characteristics, Agency Factors, PSX listed firms.

A profit share to be distributed between the shareholders based on their total share in investment is known as Dividend (Pamela 2008). Whereas, according to Hashemijoo et al., (2012), the firm's policy is to decide shareholder's dividend portion as well as Retained earnings. According to the "stock valuation model," stock value is extremely dependent on the dividend amount. Usually, dividends distributed in the form of cash or stock form. If a dividend distribution is in cash, then to do so, enough cash is required. Such activity may create a cash flow problem as the firm's profit may not be in the cash form only (Jo and Pan, 2009). A payout policy was projected by Miller and Modigliani (1961) as dividend policy, which claims that if a firm pays a high dividend, then it leads to a reduction in firm dividend later, therefore in time value, the total effect is zero. An unexpected increase in dividends considers as a bad sign. For the last 50 years, an extensive, as well as an explorative research area in corporate finance, is dividend policy which has been inspected by many and severe firm issues like clientele effect, agency cost, as well as the valuation of shares, has been faced by firms (Zakaria et al., 2012). Dividend policy impact on prominent firm variables has been by many researchers, but all lead to inconsistent results with no harmony between the researchers. Some observers claim the irrelevancy of dividends (Modigliani and Miller, 1961), whereas other researchers show contradicting views about dividend relevancy (Gordon, 1963). Black (1976) wrote about Dividend Policy and narrate that "The harder we look at the dividend picture, the more it seems like a puzzle, with pieces that just don't fit together."

A dividend distribution by the managers and why it is attractive for shareholders? This study investigates the direct impact of dividend payout on the Pakistan stock exchange (PSX) Listed firms' value and tests the direct relation of dividend policy and earning per share to conclude the mediation of agency variables. The stock price reaction towards an announcement of dividend grasps wide consideration in financial economists and accountants. Whereas, the research study of Wang (2014), proposed the direct (positive) relation of stock returns and the dividend announcement. Chaabouni (2017) evidences the reflection of information about dividend on prices of stock. A market gives an early reaction as compared to the real dividend announcement. There is information outflow relevant to the final announcements of dividends. These findings are dependable on the signaling theory.

Regarding dividend policy relationship with the stock price volatility, there is no harmony between researchers. Thus, Ullah (2015) studies the impact of dividend policy on stock price volatility in listed firms of KSE-100 under the Pakistan stock market. While, many past studies inspected the dividend policy impact on the stock price, but, only limited literature is available on such issues. Whereas, to cover the gap of existing literature, this study tries to discover the mediation of agency factors in the relation to the volatility of stock price and the policy of dividends in the Pakistani industry.

This study aims to detect whether specified agency factors (Free cashflow or total institutional ownership structure) show mediation with the dividend policy impact on Firm Characteristics include "enterprise value, earning per share, stock return and volatility" in PSX-listed firms.

\section{Literature review}

"Several investigators report a decision relative to what part of the dividend should be distributed in the form of cash to the shareholders in return of their shares" (Pettit,1972; Lonie et al., 1996; Power, McCluskey, Burton \& Sinclair, 2006;).

"The effects of Dividend policy on shareholder's wealth" is an unknown domain widely debated in the literature of finance (Rafique, 2012). Anichebe, Okoye, and Ozuomba, (2016) revealed that dividend policy is significantly associated with wealth

${ }^{123}$ Institute of management sciences, Bahauddin Zakariya University Multan, Pakistan, toobatooba2794@ gmail.com 
maximization. An investigative study was done by Widyastuti (2016) to check the positive impact of dividend policy on firms' value. The wealth of shareholders influenced by the Dividend policy in the Sri Lankan economy Dilshani (, 2018). Positive relation of DPS and ROE is noticed by Laily (2018) with the proposed negative association of DPR and the wealth of shareholders.

In the Pakistani textile and energy sectors Ahmad, Hasan, Rafiq, and Rehman (2015) initiate a negative relationship between dividend policy and earnings per share. In the Pakistani economy, by using 30 firms. Ansar, et al. (2015) studied from many sectors, to define the strong relation of stockholders' wealth and dividend payout. In 1961, Modigliani and Miller claimed that the firm's value doesn't influence dividend policy. To study dividend policy impact, Widyastuti (2016) directs research, which provides a positive association of firm value and dividend policy. Whereas in Pakistan, the effect of firm characteristics is examined by Mirza and Azfa (2010) on the firm's dividend policy. By taking $70 \mathrm{KSE}$ listed firms, Fida et al. (2012) observe the firm's dividend policy, which contradicts the results of Mirza and Azfa (2010). Asghar et al., (2011) expand Nishat and Irfan's (2004) work that claims that in Pakistan, the stock price is under the dividend policy risk.

Fama and Babiak (1968), conclude that dividend payout policy is positively related to institutional ownership, but Kumar (2003), Azzam (2010), Eskandor, Mehrani, and Moradi (2011), and Mirzae (2012) found negative relation of dividend policy and institutional shareholders. Afandi (2015) conduct a study to define the positive effect of free cash flow, foreign and family ownership directly on dividend policy. Shaheen's (2018) study specified a positive link of institutional ownership but the negative link of insider ownership with dividend policy. Change in Dividend is a source of knowledge about the firm cash flows. Between cash flow and changes in Dividend Adelegan (2003) found a significant relation. Dividends cut extra cash concluded in Smith et al. (2017) study, whereas in Pakistan. Imran (2011) discovered a positive influence on dividend policy and negative link of size and cash flows.

The dividend announcement impact of the stock prices is examined by Chaabouni (2017) in the Saudi Arabian economy and discover the significant influence of dividend announcements on share prices. Reduction in government expenditure leads to a higher dollar price, and the supply of money positively affects inflation. Iqbal (2019). On the other hand, Irum, Rafique \& Hassan (2012) observed no relation between Dividend and stock prices. Amman Stock Exchange observed by AlQudah \& Yusuf (2015), and Ahmed et al. (2018) conclude a negative impact of Dividend on share price volatility. In the contest of the Malaysian Stock Exchange, Zainudine (2018) discovers the relation of dividend policy and volatility of the stock price. A positive link between Dividend and share price volatility disclosed by Hamid et al. (2017) by taking the financial sector, while Nazir et al. (2010), Shah and Noreen (2016) examine the non-financial sector in KSE. Other than developed economies, Pakistani firms have more cash (Dittmar et al., 2007). Shareholders not protected in Pakistan, (Ghani \& Ashraf, 2005; Saeed, Belghitar, \& Clark, 2014), but they attract firms' cash holding. Components of Cashflow statement are interrelated, whereas main components account receivables, cash, and inventory are revealed by (Acharya, Davydenko, \& Strebulaev, 2012; Belo \& Lin, 2012; Banker, Byzalov, Ciftci, \& Mashruwala, 2014; Lemmon, Liu, Mao, \& Nini, 2014). Sheikh and Khan (2016) proposed that if a firm has excess cash, the board size, and insider ownership, it will influence the firm value. In the Tehran Stock exchange, Galogah, Pouraghajan \& Makrani (2013) found a negative relation between stock return and free cash flows, whereas, (Pouraghajan, Tabari \& Emamgholipour, 2013) propose no association between measures of financial performance and free cashflows. The stability of income reduction with higher insolvency risk leads to increased fee income generated with bank involvement (Iqbal, 2018).

Association of institutional ownership and enterprise value is evident by Thanatawee (2014), which concludes a positive impact on firm value. Such ownership structure highly linked with lower enterprise value. Equity-based financing firms show a weak dual effect of leverage on the risk and profitability (Iqbal, 2018). As proposed by Ajay (2015), firms with high institutional holdings have a higher quality of earnings.

Impact of change in ownership and stock returns is evident through several studies (Jones, Lee, and Weis 1999; Nofsinger and Sias 1999; Wermers 1999, 2000; Cai, Kaul, and Zheng 2000; Bennett, Sias, and Starks 2003; Parrino, Sias, and Starks 2003). CSR award announcement directly reflects on the share prices, but firms don't bother it. (Iqbal 2019) To determine the relation of in own and stock volatility, Rubin and Smith (2009) conclude that this relationship is dependent on the firm's dividend policy. The study also states that in firms not paying dividends, ownership shows a negative link with stock volatility.

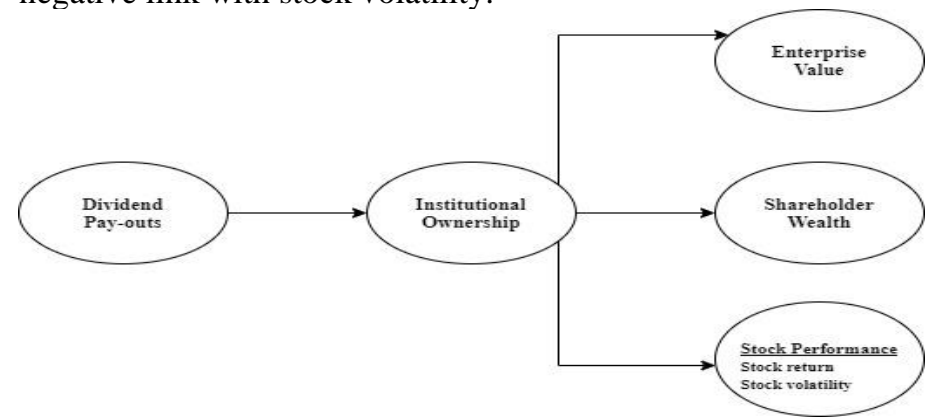

Figure 1: Theoretical framework of impact of dividend policy on firm characteristics under mediation of institutional ownership

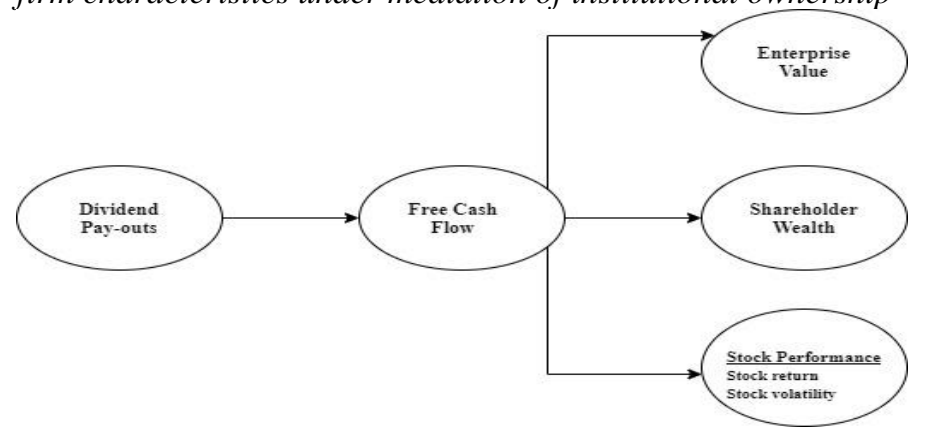

Figure 2: Theoretical framework of impact of dividend policy on firm characteristics under mediation of free cashflow. 


\section{Research Methodology}

This study observes either agency factors (Free cashflows \& Total institutional ownership) mediate the relationship of dividend policy and firm characters. This study includes firm characteristics such as enterprise value, shareholders' wealth, stock return, and volatility as dependent variables. Whereas, agency factors such as free cashflow and Total institutional ownership taken as a proxy for mediation measures. The independent variable is dividend payout. Dataset collected from the annual reports of listed firm's available on firm websites, PSX websites, and State Bank of Pakistan. A sample of 130 listed firms from Pakistan stock exchange has taken over eleven years (2008-2018).

According to "Structural equation modeling technique" of Newsom (2018) the econometric models to examine the relationship are:

$\mathrm{DPR}=f($ Enterprise Value, EPS, Stock Return and Volatility| PSX Listed Firms)

$\mathrm{DPR}=f($ Enterprise Value, EPS, Stock Return and Volatility, FCF | PSX Listed Firms)

$\mathrm{DPR}=f$ (Enterprise Value, EPS, Stock Return and Volatility, Institutional Ownership | PSX Listed Firms)

Table 1: Measurements of Variables

\begin{tabular}{|c|c|c|}
\hline Variables & Signs & Definition \\
\hline Dividend payout ratio & DPR & Total dividends / Net income \\
\hline Free Cashflow & $\mathrm{FCF}$ & $\begin{array}{llll}\begin{array}{l}\text { Operating cash } \\
\text { expenditures }\end{array} & \text { flow- } & \text { Capital } \\
\end{array}$ \\
\hline $\begin{array}{l}\text { Institutional } \\
\text { Ownership }\end{array}$ & INOWN & $\%$ owned firm's shares by institutions \\
\hline Shareholder's Wealth & EPS & $\begin{array}{l}\text { (Net Income - Preferred Dividends) / } \\
\text { Number of Common Shares Outstanding }\end{array}$ \\
\hline Enterprise Value & EV & $\begin{array}{l}\text { Market Capitalization+ Debt- Total cash } \\
\text { and cash equivalent }\end{array}$ \\
\hline $\begin{array}{l}\text { Stock Return } \\
\text { Stock Volatility }\end{array}$ & $\begin{array}{l}\mathrm{R} \\
\mathrm{r} .\end{array}$ & $\begin{array}{l}\text { Dividend yield+ Capital Gains yield } \\
\text { Standard deviation of the daily total } \\
\text { return for a given year }\end{array}$ \\
\hline
\end{tabular}

\section{Empirical results}

The descriptive statistics include standard deviation, median, mean, variance, kurtosis, and skewness of all variables. Enterprise Value (EV) mean value is the highest (15.213) among DVs. The variation in data explained through the standard deviation. The highest standard deviation value is 10.162 for enterprise value (EV) with a standard deviation of DPR (4.233). The summary of descriptive statistics is reported in Table 2.

Table 2: Descriptive Statistics

\begin{tabular}{lccccccc}
\hline Variables & DPR & EV & EPS & R & R & FCF & $\begin{array}{c}\text { T } \\
\text { IOWN }\end{array}$ \\
\hline Mean & .580 & 15.21 & 1.03 & -.09 & 2.48 & 5.99 & 1.35 \\
Median & .173 & 9.72 & 1.03 & .799 & 2.38 & .88 & 3.00 \\
Standard & 4.23 & 10.16 & 2.07 & 1.43 & 1.74 & 8.75 & 2.07 \\
Deviation & & & & & & & \\
Variance & 17.92 & 103.26 & 4.31 & 2.06 & 3.03 & 76.58 & 4.31 \\
Skewness & 27.54 & -.531 & - & -1.6 & .122 & 1.04 & -.664 \\
& & & 1.23 & & & & \\
Kurtosis & 878.55 & 1.59 & 5.22 & 8.57 & 2.93 & 2.212 & 2.31 \\
\hline
\end{tabular}

DPR: Dividend Payout Ratio, EV: Enterprise Value, EPS: Earning Per Share, R: Stock Return, r: Stock Volatility, FCF: Free Cashflows, TIOwn: Total Institutional Ownership

The correlation between dependent variables while agency factors as mediators and dividend payout ratio as the independent variable tested at $1 \%$ and $5 \%$ level of significance. Results conclude that
EV, EPS, r, and FCF significantly related to DPR at a $1 \%$ level of significance. At the same time, there is a significant relation of $\mathrm{R}$ with DPR (at the significance $=5 \%$ ). Table 4 present insignificant relationship of FCF and EPS (at the level of significance=5\%), whereas the association of FCF with $\mathrm{EV}, \mathrm{R}$, and $\mathrm{r}$ to be significant (at 5\% level of significance) and the relation between EPS and R, $r$ to be significant (at 5\% level). The summary of the results presented in Table 3.

Table 3: Statistics for correlation between variables

\begin{tabular}{lccccccc}
\hline Measures & DPR & FCF & EPS & EV & R & R & TIOwn \\
\hline DPR & 1 & & & & & & \\
FCF & $.0017^{*}$ & 1 & & & & & \\
EPS & $.0035^{*}$ & .2147 & 1 & & & & \\
EV & $-.0016^{*}$ & $.0383^{* *}$ & $-.0037^{*}$ & 1 & & & \\
R & $.0313^{*}$ & $.0289^{* *}$ & $.0161^{* *}$ & $-.013^{* *}$ & 1 & & \\
R & $.0036^{*}$ & $.0409^{* *}$ & $.0110^{* *}$ & .5951 & .597 & 1 & \\
TIOwn & -.0707 & -.1377 & -.0552 & -.1255 & $-.000^{*}$ & -.134 & 1 \\
\hline
\end{tabular}

*Correlation is significant at the 0.01 level, **Correlation is significant at the 0.05 level.

DPR: Dividend Payout Ratio, EV: Enterprise Value, EPS: Earning Per Share, R: Stock Return, r: Stock Volatility, FCF: Free Cashflows, TIOwn: Total Institutional Ownership

To test autocorrelation, "Durbin Watson test" is applied to estimate the standard errors (Weber \& Monarchi, 1982). Value of d-statics lies between "1.5-2.5" is acceptable Aga \& Safakli (2007), Prusty (2010, p.55), Vogt \& Johnson (2011, p.118). Test results of autocorrelation are within "1.5-2.5", which concludes no autocorrelation. Summary of Durbin Watson's test results is in Table 4.

Table 4: Durbin watson test

\begin{tabular}{|c|c|}
\hline Durbin Watson Statics & \\
\hline No of firms $=130$ & d-statics \\
\hline No of observation $=1430$ & $1.993543^{*}$ \\
\hline
\end{tabular}

To fit a linear regression to the model test for heteroscedasticity applied to check the biasness in residuals. Results give p-value < 0.05 means heteroscedasticity exist. So, corrections needed to normalize the p-values. Summary of test displayed in Table 5.

Table 5: Heteroscedasticity test

\begin{tabular}{ll}
\hline \multicolumn{2}{c}{ Breusch-Pagan / Cook-Weisberg Test for Heteroskedasticity } \\
\hline $\mathrm{H}_{0}$ & Constant Variance \\
Variables & Fitted Values for LnFCF \\
Chi2(1) & 759.52 \\
Prob $>$ chi2 & $0.0000^{* *}$ \\
\hline
\end{tabular}

$* *$ p-value statistic $<0.05$ (Heteroscedasticity exist)

Table 6: Robust Heteroscedasticity Test

Variables $\quad$ Linear Regression Statics $\quad$ Robust Statics

\begin{tabular}{lllll}
\hline FCF & $\mathrm{p}$-values & Stand error & $\mathrm{p}$-values & Robust stand error \\
$\mathrm{EV}$ & 0.000 & .0219 & 0.000 & .0138 \\
$\mathrm{R}$ & 0.055 & .1151 & 0.042 & .1087 \\
$\mathrm{R}$ & 0.000 & .1035 & 0.000 & .1003 \\
TIOwn & 0.000 & .1086 & 0.000 & .1111 \\
EPS & 0.385 & .0834 & 0.394 & .0849 \\
DPR & 0.564 & .0391 & 0.341 & .0237 \\
-cons & 0.000 & .5321 & 0.000 & .4707 \\
\hline
\end{tabular}

DPR: Dividend Payout Ratio, EV: Enterprise Value, EPS: Earning Per Share, R: Stock Return, r:Stock Volatility, FCF: Free Cashflows, TIOwn: Total Institutional Ownership

Table 7: Regression Statics (Random Effect)

\begin{tabular}{|c|c|c|c|c|c|c|c|}
\hline Model & Varial & & & Coefficient & S. E & $\mathbf{Z}$ & $\mathbf{p}>|\mathbf{z}|$ \\
\hline & IVs & DVs & Meds & & & & \\
\hline \multicolumn{8}{|c|}{ 1-Direct relation of IVs and DVs } \\
\hline 1 & $\begin{array}{l}\text { DPR } \\
\text { cons }\end{array}$ & EPS & - & $\begin{array}{l}-.04647 \\
1.0575\end{array}$ & $\begin{array}{l}.00839 \\
.15884\end{array}$ & $\begin{array}{l}-5.54 \\
6.66\end{array}$ & $\begin{array}{l}.000^{* *} \\
.000^{* *}\end{array}$ \\
\hline
\end{tabular}




\begin{tabular}{|c|c|c|c|c|c|c|c|}
\hline \multirow[t]{2}{*}{2} & DPR & EV & - & -.0161 & .02310 & -.70 & .484 \\
\hline & -cons & & & 15.222 & .70349 & 21.64 & .000 \\
\hline \multirow[t]{2}{*}{3} & DPR & $\mathrm{R}$ & - & .0064 & .01015 & .64 & .524 \\
\hline & _cons & & & .2282 & .01766 & 12.92 & .000 \\
\hline \multirow[t]{2}{*}{4} & DPR & $\mathrm{R}$ & - & .0236 & .00453 & 5.21 & $.000 * *$ \\
\hline & _cons & & & 2.470 & .12565 & 19.66 & $.000 * *$ \\
\hline \multicolumn{8}{|c|}{ 2-Direct relation of IVs and Meds } \\
\hline \multirow[t]{2}{*}{5} & DPR & - & FCF & .04353 & .01491 & 2.92 & $.004 * *$ \\
\hline & _cons & & & 5.9669 & .60738 & 9.82 & $.000 * *$ \\
\hline \multirow[t]{2}{*}{6} & DPR & - & TIOwn & -.0082 & .00140 & -5.87 & $.000 * *$ \\
\hline & cons & & & 1.3615 & .17998 & 7.56 & $.000 * *$ \\
\hline \multicolumn{8}{|c|}{ 3-Direct relation of DVs and Meds } \\
\hline \multirow[t]{2}{*}{7} & - & EPS & FCF & .0076 & .00486 & 1.58 & .114 \\
\hline & _cons & & & 9845 & 16099 & 6.12 & .000 \\
\hline \multirow[t]{2}{*}{8} & - & EV & FCF & .3066 & .02852 & 10.75 & $.000 * *$ \\
\hline & _cons & & & 13.375 & 66601 & 20.08 & $.000 * *$ \\
\hline \multirow[t]{2}{*}{9} & & $\mathrm{R}$ & FCF & -.0118 & .00406 & -2.92 & $.004 * *$ \\
\hline & _cons & & & -.0217 & .05271 & -.41 & $.680 * *$ \\
\hline \multirow[t]{2}{*}{10} & - & $\mathrm{R}$ & FCF & 2.1140 & 1.2348 & 1.71 & .087 \\
\hline & _cons & & & 44.575 & 8.2949 & 5.37 & .000 \\
\hline \multirow[t]{2}{*}{11} & - & EPS & TIOwn & -2.708 & 2.3699 & -1.14 & .253 \\
\hline & _cons & & & 27.411 & 14.004 & 1.96 & .050 \\
\hline \multirow[t]{2}{*}{12} & - & EV & TIOwn & -.6575 & .02866 & -22.9 & $.000 * *$ \\
\hline & _cons & & & 23.542 & .39010 & 60.35 & $.000 * *$ \\
\hline \multirow[t]{2}{*}{13} & & $\mathrm{R}$ & TIOwn & .04009 & .01942. & 2.06 & $.039 * *$ \\
\hline & _cons & & & -.1470 & .04493 & -3.27 & $.001 * *$ \\
\hline \multirow[t]{2}{*}{14} & & $\mathrm{R}$ & TIOwn & -.1520 & .04541 & -3.35 & $.001 * *$ \\
\hline & cons & & & 2.690 & .12520 & 21.49 & $.000 * *$ \\
\hline
\end{tabular}

**p-value statistic $<0.05$ (Significant relation exist)

Under regression analysis, direct relation among IVs and DVs, whereas direct relation of IV and Mediators as well as Mediators and DVs, also tested. Firstly, the whole model divided into different sub-models according to relation exists. Table 4 provides complete regression statics of models. Model 1 provides results of the relationships among variables, both independent (DPR) and dependent (EPS), hold significance (p-value <0.05). Model 2 and Model 3 that lacked statistical significance with DPR were EV and $\mathrm{R}$, hold p-value $>0.05$, which is insignificant. Model 4 also hold significance $(\mathrm{p}$-value $<0.05)$ which show significant relation among variables. These results of direct relation among independent and dependent variables indicate that only two variables from the chosen variables make a significant contribution. Part 2 of Table 5 shows regression statics of the direct relation of independent and mediating variables. The model 5 provides results of the relationships among variables, both independent (DPR) and mediator (FCF), hold significance ( $\mathrm{p}$ value $<0.05)$. Model 6 also hold significance ( $p$-value $<0.05$ ) which show significant relation among variables. These results of direct relation among independent and mediating variables indicate that both mediating variables contribute significantly. Part 3 of Table 5 provides regression results for direct relation among mediating and dependent variables. Model 7 shows the relation among FCF and EPS with p-value >0.05, which shows insignificant relation, while model 8 and model 9 show p-value $<0.05$, which is significant. Model 10 holds p-value $>0.05$, which is insignificant. Model 11 shows the relation among TIOwn and EPS with p-value $>0.05$, which shows insignificant relation while modeling 12-14 show p-value $<0.05$, which is a significant relation. Mediation assessed using by applying the Sobel test is applied.
Table 8: Sobel Test Statics

\begin{tabular}{llll}
\hline Measures & T-statistics & P-Value & Standard Error \\
\hline DPR-FCF-EPS & 1.3786995 & 0.16798742 & 0.00023996 \\
DPR-FCF-Ev & 2.8192285 & 0.00481392 & 0.00473402 \\
DPR-FCF-R & -2.06044622 & 0.00024929 & 0.0393559 \\
DPR-FCF-r & 1.47708063 & 0.13965403 & 0.0623002 \\
DPR-TIOwn-EPS & 1.12152115 & 0.26206609 & 0.01979954 \\
DPR-TIOwn-Ev & 5.67510316 & 0.000000008 & 0.00095003 \\
DPR-TIOwn-R & -1.94697599 & 0.05153761 & 0.00016885 \\
DPR-TIOwn-r & 2.90618019 & 0.00365871 & 0.00042888 \\
\hline
\end{tabular}

Table 8 provides the statistics for the Sobel test results, which include P-value, t-statistics, and standard error. The mediation measures between the relationship of DPR with EPS and $r$ (taking FCF as a mediator). The p-value of the result is greater than the significant level of $\mathrm{p}<0.05$, whereas for the next two measures of FCF mediation on the relation of DPR with Ev and R the $p<0.05$, which shows the significant mediation of FCF on the relation. The measures of mediation between the relationship of DPR with EPS (taking TIOwn as a mediator). The p-value of the result is greater than the significant level of $\mathrm{p}<0.05$, whereas for the next three measures of TIOwn mediation on the relation of DPR with Ev, R, and $r$ the $p<0.05$, which show the significant mediation of TIOwn on the relation.

\section{Discussion}

The results show that FCF shows significant positive mediation on dividend payout's relation with some specific characteristics such as Enterprise value and stock return. Still, there is mediation occur on the relationship of DPR with earning per share and stock volatility. Whereas, other agency factors total institutional ownership show mediation on the relation of DPR with enterprise value, stock return, and volatility as the test shows, the role of these mediators with some relationships was not significant.

\section{Conclusion}

This study intends to understand the mediating role of agency factors on the impact of dividend policy. This study is equally significant in the existing literature. Every part of the research is a revelation of payout policy effect on the firm characteristics with the interceding role of agency factors. This paper delineates the agency factors such as Institutional Ownership and FCF as a referring body in the relation of dividend policy with each firm characteristic. But our findings found the non-existence of mediation in the relationship of dividend payouts with each firm characteristic. These understandings are remarkable and diverse from preceding studies.

Moreover, it reveals that with the existence of free cash flows, dividend payouts positively influence the enterprise value and improve the firm's stock performance (stock return). But the impact of dividend payout on firm characteristics still exists as there are no free cashflows in the firm. It is because free cash flow only considered as cash of the firm; it is not related to the payouts and other firm characteristics directly, but its presence accelerates the relation of Payouts and firm characteristics. Furthermore, this study also tests the mediation with institutional ownership on the relationship between Dividend payouts and firm characteristics. The results demonstrate the significant mediation of institutional ownership on dividend payout's relationship with Enterprise Value and Stock Performance (including the stock return and volatility). 
It reveals that institutional ownership in the firm accelerates the relation of dividend payout with enterprise value. This is because the higher the institutional ownership in the firm, the more the value of shareholders will be with the dividend payout, which leads to the increase in the stock performance.

As cited previously, fairly several qualitative workings done in the arena of the impact of dividend payout under mediation, but very little pragmatic evidence is present. This study tried to fill out the gap by accompanying empirical research to know the mediating character of agency factors on the influence of dividend payout on firm characteristics in Pakistan's context.

\section{Implications and Suggestion for Future Research}

Under the empirical finding this study, this paper has been able to deliver a better understanding of the mediating role of Free cashflow and institutional ownership in the relation of dividend payout and firm characteristics in the Pakistani context. For PSX listed firm's implication of the study is that the firms should have free cashflow and institutional ownership to get more influence of dividend payouts on the firm characteristics. The solution to this situation is that the firms must keep free cash flow to increase the impact of dividend payout on the firm's value and the performance of firm stock such as Stock return. On the other hand, in case of the mediating role of institutional ownership firm needs to increase the concentration of institutional ownership to improve the impact of dividend payout on the enterprise value and stock performance. Future researches may explore the real issue in other sectors of Pakistan or across the boundaries.

\section{References}

Acharya, V., Davydenko, S. A., \& Strebulaev, I. A. (2012). Cash holdings and credit risk. The Review of Financial Studies, 25(12), 3572-3609.

Adelegan, O. J. (2003). Capital market efficiency and the effects of dividend announcements on share prices in Nigeria. African Development Review, 15(2-3), 218-236.

Afza, Talat, \& Mirza, Hammad Hassan. (2010). Ownership Structure and Cash Flows as Determinants of Corporate Dividend Policy in Pakistan. International Business Research, 3(3), 210-221.

Aga, M., \& Safakli, O. V. (2007). An empirical investigation of service quality and customer satisfaction in professional accounting firms: Evidence from North Cyprus. Problems and Perspectives in Management, 5(3), 84-98.

Ahmad, M. A., Alrjoub, A. M. S., \& Alrabba, H. M. (2018). The effect of dividend policy on stock price volatility: empirical evidence from amman stock exchange. Academy of Accounting and Financial Studies Journal, 22(2), 1-8.

Ajay, R., \& Madhumathi, R. (2015). Institutional ownership and earnings management in India. Indian Journal of Corporate Governance, 8(2), 119-136.

Al Qudah, A., \& Yusuf, D. (2015). Stock Price Volatility and Dividend Policy in Jordanian Firms. Research Journal of Finance and Accounting, 6(22), 149-159.

Ansar, I., Butt, A. A., \& Shah, S. B. (2015). Impact of dividend policy on shareholder's wealth. International Review of Management and Business Research, 4(1), 89-95.
Asghar, M., Shah, S. Z. A., Hamid, K., \& Suleman, M. T. (2011). Impact of dividend policy on stock price risk: Empirical evidence from equity market of Pakistan. Far East Journal of Psychology and Business, 4(1), 45-52.

Ashraf, J., \& Ghani, W. I. (2005). Accounting development in Pakistan. The International Journal of Accounting, 40(2), 175201.

Azzam, I. (2010). The impact of institutional ownership and dividend policy on stock returns and volatility: Evidence from Egypt. International Journal of Business, 15(4), 443.

Azam, M. (2010). Factors influencing the price-earnings multiples and stock values in the Karachi stock exchange. Interdisciplinary Journal of Contemporary Research in Business, 2(5), 105-139.

Banker, D., and D. Byzalov. (2014). Asymmetric cost behavior. Journal of Management Accounting Research 25(2), 43-79.

Bazdresch, S., Belo, F., \& Lin, X. (2012). Internet Appendix to: Labor Hiring, Investment, and Stock Return Predictability in the Cross Section. Journal of Political Economy, 15(1), 1-39.

Bennett, James, R.W. Sias, and L.T. Starks, (2003). Greener Pastures and the Impact of Dynamic Institutional Preferences. Review of Financial Studies, 16, 1203-38.

Black, F., \& Scholes, M. (1974). The effects of dividend yield and dividend policy on common stock prices and returns. Journal of Financial Economics, 1(1), 1-22.

Cai, F., G. Kaul, and L. Zheng, (2000). Institutional trades and stock returns. Working paper, University of Michigan.

Dilshani, L. D. C., \& Abeywardhana, D. K. Y. (2018). The Impact of dividend policy on shareholders' wealth and business performance of listed manufacturing companies in Sri Lanka. 4th International Conference for Accounting Researchers and Educators, Department of Accountancy, Faculty of Commerce and Management Studies, University of Kelaniya, Sri Lanka.

Dittmar, A., \& Mahrt-Smith, J. (2007). Corporate governance and the value of cash holdings. Journal of Financial Economics, 83(3), 599-634.

Fabozzi, F. J., \& Drake, P. P. (2008). Dividend and dividend policies. Handbook of Finance, 2.

Fairchild, R., Guney, Y., \& Thanatawee, Y. (2014). Corporate dividend policy in Thailand: Theory and evidence. International Review of Financial Analysis, 31, 129-151.

Fama, E. F., \& Babiak, H. (1968). Dividend policy: An empirical analysis. Journal of the American Statistical Association, 63(324), 1132-1161.

Galogah, S. A., Pouraghajan, A., \& Makrani, K.F. (2013). The investigation of relationship between free cash flows and stock return: Evidence from the Tehran stock exchange. World of Sciences Journal, 1(12), 62-69.

Hamid, K., Khurram, M.U. and Ghaffar, W. (2017). Juxtaposition of micro and macro dynamics of dividend policy on stock price volatility in financial sector of Pakistan: (comparative analysis through common, fixed, random and GMM effect). Journal of Accounting, Finance and Auditing Studies, 3(1), 64-79.

Hasan, M., Ahmad, M. I., Rafiq, M. Y., \& Rehman, R. U. (2015). Dividend payout ratio and firm's profitability. Evidence from Pakistan. Theoretical Economics Letters, 5(03), 441. 
Hashemijoo, M., Mahdavi-Ardekani, A., \& Younesi, N. (2012). The impact of dividend policy on share price volatility in the Malaysian stock market. Journal of Business Studies Quarterly, 4(1), 111-129.

Imran, K. (2011). Determinants of dividend payout policy: A case of Pakistan engineering sector. The Romanian Economic Journal, 41(14), 47-59.

Irum, M., Rafique, M., \& Hassan, A. (2012). Effect of dividend announcement on share prices of petroleum industry of Pakistan. Journal of Basic and Applied Scientific Research, 2(7), 6503-6511.

Jo, H., \& Pan, C. (2009). Why are firms with entrenched managers more likely to pay dividends? Review of Accounting and Finance, 8(1), 87-116.

Jones, S., Lee, D., \& Weis, E. (1999). Herding and feedback trading by different types of institutions and the effects on stock prices. Unpublished working paper, Indiana University, Indianapolis Kennesaw State University, Kennesaw GA, and Merrill Lynch and Company, New York.

\section{Kumar}

(2003), http://www.iamot.org/conference/index.php/ocs/4/paper/viewF ile/928/367

Laily, a. D. I. (2018). Pengaruh good corporate governance, profitabilitas, dan kebijakan dividen terhadap nilai perusahaan (doctoral dissertation, stiesia surabaya). Assessed 15th march,2011.

Lemmon, M., Liu, L. X., Mao, M. Q., \& Nini, G. (2014). Securitization and capital structure in nonfinancial firms: An empirical investigation. The Journal of Finance, 69(4), 17871825

Linnenluecke, M. K., Chen, X., Ling, X., Smith, T., \& Zhu, Y. (2017). Research in finance: A review of influential publications and a research agenda. Pacific-Basin Finance Journal, 43, 188199.

Lonie, A. A., Abeyratna, G., Power, D. M., \& Sinclair, C. D. (1996). The stock market reaction to dividend announcements: A UK study of complex market signals. Journal of Economic studies, 23(1), 32-52.

Mehrani, S., Moradi, M., \& Esk, H. (2011). Ownership structure and dividend policy: Evidence from Iran. African Journal of Business Management, 5(17), 7516-7525.

Mirza, H. H., \& Azfa, T. (2010). Ownership structure and cash flows as determinants of corporate dividend policy in Pakistan. International Business Research, 3(3), 210-221.

Mirzael, H. (2012). A survey of the relationship between ownership structure and dividend policy in Tehran stock exchange. International Conference on Management, Applied and Social Sciences, Dubai

Modigliani, F. (1961). Dividend Policy, Growth, and the Valuation of Shares. The Journal of Business, 34(4), 411. doi: $10.1086 / 294442$

McCluskey, T., Burton, B. M., Power, D. M., \& Sinclair, C. D. (2006). Evidence on the Irish stock market's reaction to dividend announcements. Applied Financial Economics, 16(8), 617-628.

Nazir, M. S., Nawaz, M. M., Anwar, W., \& Ahmed, F. (2010). Determinants of stock price volatility in Karachi stock exchange: The mediating role of corporate dividend policy. International Research Journal of Finance and Economics, 55(55), 100-107

Newsom, J. T. (2018). Minimum sample size recommendations (Psy 523/623 structural equation modeling, Spring 2018). Manuscript Retrieved from upa. pdx. edu/IOA/newsom/semrefs. htm.

Nishat, M., \& Irfan, C. M. (2004). Dividend policy and stock price volatility in Pakistan. In Pide-19th annual general meeting and conference (pp. 13-15).

Nofsinger, John, and R.W. Sias, (1999). Herding and Feedback Trading by Institutional and Individual Investors. Journal of Finance, 54, 2263-95.

Ozuomba, C. N., Anichebe, A. S., \& Okoye, P. V. C. (2016). The effect of dividend policies on wealth maximization-a study of some selected plcs. Cogent Business \& Management, 3(1), 1226457.

Parrino, R., Sias, R. W., \& Starks, L. T. (2003). Voting with their feet: Institutional ownership changes around forced CEO turnover. Journal of Financial Economics, 68(1), 3-46.

Pettit, R. (1972). Dividend Announcements, Security Performance, and Capital Market Efficiency. The Journal Of Finance, 27(5), 993. doi: 10.2307/2978844 Wallingford, B. (1972).

Pouraghajan, A., Tabari. Y. N., \& Emamgholipour, M. (2013). The effect of free cash flows and agency costs on the performance of listed companies in the Tehran Stock Exchange. World of Sciences Journal, 1(6), 1-10.

Prusty, S. (2010). Managerial economics. PHI Learning Pvt. Ltd.. Rafique, M. (2012). Factors affecting dividend payout: Evidence from listed non-financial firms of Karachi stock exchange. Business Management Dynamics, 1(11), 76.

Rubin, A., \& Smith, D. R. (2009). Institutional ownership, volatility and dividends. Journal of Banking \& Finance, 33(4), 627-639.

Saeed, A., Belghitar, Y., \& Clark, E. (2014). Theoretical motives of corporate cash holdings and political connections: firms level evidence from a developing economy. International Review of Applied Economics, 28(6), 813-831.

Shah, S. A., \& Noreen, U. (2016). Stock price volatility and role of dividend policy: Empirical evidence from Pakistan. International Journal of Economics and Financial Issues, 6(2), 461-472.

Shaheen, R., \& Ullah, S. (2018). Effect of institutional and insider ownership on dividend policy: Evidence from Pakistan. Journal of Business and Tourism, 04(02), 181-192.

Sheikh, N. A., \& Khan, M. I. (2016). Effects of excess cash, board attributes and insider ownership on firm value: evidence from Pakistan. Australasian Accounting, Business and Finance Journal, 10(1), 29-39.

Suhartono, A. (2015). The Effect of free cash flow and ownership structure on dividend payout ratio in manufacturing companies in Indonesia. The Indonesian Accounting Review, 5(2), 129140.

Ullah, H., Fida, A., \& Khan, S. (2012). The impact of ownership structure on dividend policy evidence from emerging markets 
KSE-100 Index Pakistan. International Journal of Business and Social Science, 3(9), 298-307.

Ullah, H., Saqib, S. E., \& Usman, H. (2016). The impact of dividend policy on stock price volatility: A Case study of selected firms from textile industry in Pakistan. International Journal of Academic Research in Economics and Management Sciences, 5(3), 1-11.

Vogt, W. P., \& Johnson, B. (2011). Dictionary of statistics \& methodology: A nontechnical guide for the social sciences. Sage.

Wang, C., \& Liu, X. (2014). Dividend problems in the diffusion model with interest and exponentially distributed observation time. Journal of Applied Mathematics, 2014, 1-6.

Weber, J. E., \& Monarchi, D. E. (1982). Performance of the durbin-watson test and WLS estimation when the disturbance term includes serial dependence in addition to first-order autocorrelation. Journal of the American Statistical Association, 77(377), 117-128.

Wermers, R., (1999). Mutual fund trading and the impact on stock prices. Journal of Finance, 54, 581-622.

Wermers, R., (2000). Mutual fund performance: An empirical decomposition into stock-picking talent, style, transaction costs, and expenses. Journal of Finance, 55, 1655-1695.

Widyastuti, P., \& Suhadak, M. (2016). The influence of financial performance and dividend policy on firm value. Journal of Business Studies, 2(1), 1-25.

Zakaria, Z., Muhammad, J., \& Zulkifli, A. H. (2012). The impact of dividend policy on the share price volatility: Malaysian construction and material companies. International Journal of Economics and Management Sciences, 2(5), 1-8.

Zainuddin, Z., Tapa, A., \& Rahim, A. I. A. (2018, September). Examine the financial health of the listed technology companies in Malaysia using Altman's Z-score test. In AIP Conference Proceedings (Vol. 2016, No. 1, p. 020144). AIP Publishing. 